\title{
Os fundos de investimento. Condomínios mobiliários.
}

\author{
Félix Ruiz Alonso
}

\section{Introdução}

O Mercado de Capitais, nestes últimos anos, tem chamado a atenção de todos e tem-se convertido num dos principais instrumentos pós-revolucionários, a serviço da política de investimentos.

Numa atmosfera desenvolvimentista uma série de institutos financeiros, já existentes, foram remoçados e outros novos criaram-se. Entre êstes, contam-se os Fundos de Investimentos.

E verdade que os Fundos em Condomínio, legalmente, tiveram início em 30.11.1959, com a Portaria $\mathrm{n}^{\text {o: }} 309$, em que se permitiu às Companhias de Crédito e Financiamento "a constituição de fundos em condomínio". Não obstante isso, anteriormente, alguns fundos, sob a forma de condomínio, já funcionavam no país. De resto, as Companhias de Investimentos, sob a forma de sociedade, tinham sido criadas em 1945 (Decreto-lei $\mathrm{n}^{\circ}$ 7.853) e 1946 (Decreto-lei $\mathrm{n}^{\circ}$ 9.603). Todavia, prescindindo das primeiras instituições pioneiras neste ramo dos negócios, o fenômeno dos investimentos como tal, começou a eclodir em data recente. No ano de 1969, criaram-se aproximadamente 100 fundos de investimentos sob a forma de condomínios. Recentemente - Abril de 1970 -- regulamentou-os de forma completa o Banco Central do Brasil, com a Res. 145, derrogando as disposições anteriores. 
A razão do fenômeno é principalmente técnico-política. Foram as diretrizes do govêrno, - ciente do valor do binômio: poupança-investimento - as que reativaram com numerosas normas, o despertar dêste tipo de negócios. Foi a Lei de Mercado de Capitais, que deu o impulso definitivo às operações de investimentos. Veio também, a nova regulamentação da Bôlsa de Válôres. É um caso de fôrça diretriz, criativa do direito; pelo menos, como rumo e pressuposto de negócios, no âmbito econômico-mercantil.

Entre os doutrinadores nacionais, a elaboração jưridico-doutrinária dos novéis Fundos de Investimentos é ainda parca. Obra pioneira foi a de Oscar Barreto FilHo, intitulada Regime Jurídico das. Sociedades de Investimentos, de 1956; posteriormente, Bernard PaJiste escreveu Investimentos, publicado no Rio de Janeiro em 1958, e Peter Walter Ashton escreveu Companhias de Investimentos em 1963. Mais recentemente em 1966, Pontes de Miranda no tomo LI do seu Tratado de Direito Privado, dedicou os capítulos do Título LIII quase integralmente, às Sociedades de Investimentos. Foram êsses os passos dados pela doutrina, em sua evolução.

Os autores pátrios, quando se definiram, tomaram diferentes posições: Oscar Barreto Filho e Bernard Pajiste, consideram os Fundos como "sociedade em conta de participação"; Peter Walter Ashton, com Cyrne lima consideram-nos como "expectativas de condomínio" ou "spes condominii". Estes autores têm, entre outros, o grande mérito de terem escrito quando nada havia, pràticamente, sôbre a especialidade. Pontes de Miranda, mais recentemente, os considera como "Condomínios", embora não fundamente a sua opinião, sendo esta não só a sua denominação legal, mas a "opinio communis", que vai se formando à margem do direito.

Nestes últimos anos, perante o impeto jovem dum mercado que adquire as primeiras experiências, não se escreveu quase nada de nôvo. O tema é complexo. Os nossos institu- 
tos tradicionais, mais uma vez, se chocam com as figuras alienígenas. Do estrangeiro pudemos apreender apenas o "modus operandi". Cabe, agora, a nós descobrir a natureza dêsses organismos financeiros, e defini-los segundo os modêlos lógicos de nosso "ius conditum". Mais uma vez o ingrato labor de "verter vinho novo em odres velhos"!

A nossa tradição jurídica resiste à criação de figuras novas; porisso a procura do "odre velho" em que poder encaixar os Fundos de Investimentos, terá o sabor de quem quereria ter criado um instituto novo, que fôsse o protótipo dêsses fundos - um "odre novo".

Adentrando-nos no direito europeu, nota-se que alguns países, deram acolhida jurídica às novas formas, tão ágeis, dos negócios de investimentos, em institutos como o condomínio (Italia, Fspanha), e a propriedade fiduciária (Alemanha, Suissa).

Perante êste quadro, tentaremos dar alguma contribuição que será forçòsamente modesta, pela própria dificuldade e estado embrionário em que se encontra a matéria. E necessário elaborar o instituto, já que, na atualidade, êsses negócios não são mais uma expectativa futura. Os fundos de investimentos são uma realidade, entre nós. Finalmente, temos consciência de não estarmos dando a última palavra na matéria, mas de sermos mais um elo na elaboração doutrinária dos Fundos.

Nêste trabalho, centrar--nos-emos nos "Fundos de Investimentos", embora, de passagem, se façam algumas alusões às "sociedades de investimentos", por terem a mesma atividade: a aplicação em valôres mobiliários ou investimentos. 
I. Os fundos de investimentos.

1 O fato mercantil

2. Noção histórica

3. Aparecimento no Brasil

4. Sociedades de Investimentos, de capital fixo e de capital autorizado

II. O condomínio.

5. Noção de condomínio

6. O condomínio e a voluntariedade

7 O condomínio necessário ou civil

8. O condomínio voluntário imobiliário

9. O condomínio voluntário mobiliário

10. Multiplicidade de propriedades parciais

11. Precedentes doutrinários do condomínio

12. O mandato

Primeiras Conclusões

III. Forma jurídica societária.

13. Os fundos e a sociedade

14. As sociedades comerciais

15. "Affectio societatis"

16. Condomínio e sociedade

17 Propriedade e abstração matemática

18. As sociedades em conta de participação

19. Fundações e os fundos

Conclusões Finais

1 Todo investidor procura, quando efetua certo investimento, segurança, rentabilidade e liquidez. Se efetuar 
o seu investimento numa só emprêsa, naturalmente ficará à mercê da segurança, rentabilidade e liquidez que lhe possa oferecer aquela determinada emprêsa, com a ressalva de que, em se tratando de investimento em ações, a liquidez sera muito baixa, já que as ações, como parte representaliva do capital fixo, em princípio tèm baixa liquidez; sòmente aquelas que habitualmente são cotadas em bôlsa, conseguem bôa liquidez.

A maneira prática, comercialmente falando, de conseguir maior segurança, rentabiliaade e liquidez, consiste como tantas outras vêzes - em somar esforços e distribuir os riscos. Somar esforços significa serem várias, ou muitas as pessoas que realizam investimentos. Distribuir os riscos da baixa rentabilidade de determinadas ações exige investir, não apenas numa emprêsa, mas em várias, de maneira que o alto resultado de algumas compense o baixo fruto de outras, atingindo-se, assim, um resultado médio satisfatório e uma segurança, sem dúvida, também maior.

A liquidez, talvez a meta mais difícil de ser atingida, também será alcançada se o grupo de investidores se mantiver aberto, isto é, se permitirem a entrada constante de novos interessados. Desta forma se estabelece um fluxo que permite àquêles que desejarem vender a sua participação, liquidá-la com facilidade, já que haverá outros interessados em adquirí-la.

$\mathrm{O}$ arquiteto, dêsse nutrido tecido comercial, será um comerciante, constituído em administrador do fundo.

Cria-se, por esta forma, uma massa de recursos, que mantém um acêrvo variado de títulos mobiliários. Êsse acêrvo coletivo, de alguma maneira, é realidade peculiar já que atinge, em virtude da massa reunida, uns objetivos, que os investidores isoladamente não atingiriam. Ao novo comportamento mercantil, corresponde uma "coisa" nova, um fundo.

Este é o aspecto que convém, a efeitos dêste trabalho, salientar. A massa reunida pelos participantes, investidores 
ou condôminos, é uma coisa "a se", com natureza própria que alcança aquêles fins de todo investimento - segurança rentabilidade e liquidez - duma maneira ideal, mais favorável, precisamente pela sua peculiar formação. Essa a razão de ser do fundo, da nova "coisa".

Parece-nos interessante a definição que determinado autor italiano dá do negócio de investimentos, precisamente em função dessas condições mais favoráveis que propicia para a consecução dos objetivos do fundo. " $\mathrm{O}$ ' Investment Trust", diz, é um organismo financeiro que mediante a emissão de títulos próprios concentra os capitais de numerosos indivíduos a fim de aplicá-los em valores mobiliários, em condições mais favoráveis que aquelas em que o fariam cada um dos participantes, se aplicassem diretamente." 1

E nada significa a mutabilidade da massa do fundo que poderá aumentar ou diminuir, Sempre proporcionará ao investidor aquelas melhoras. Embora de maneira geral se possa dizer que a medida que a massa aumenta, aquêles objetivos serão atingidos duma maneira mais perfeita. Todavia, a administração do fundo tem uma função decisiva na marcha do mesmo; até o ponto de que uma má administração poderia anular os benefícios que uma grande massa deveria proporcionar.

É da natureza, para terminar, desta "res sui generis" que é a massa do fundo: 1. aumentar ou diminuir; 2. pertencer a múltiplas pessoas; 3 . permitir a livre entrada ou saida das mesmas; 4. atingir um ponto ótimo de segurança, rentabilidade e liquidez. Estamos perante uma realidade orgânica diferente e com características próprias.

A êsse objeto complexo deve-se acrescentar ainda a especialização do administrador em cujas mãos cobra uma operacionalidade e dinamismo novos.

1. PERLETTI G. Funzione Economica dell'Investment Trust em L'Investment Trust nelle esperienze e nei progetti europei, Cedam, $\mathrm{Pa}-$ dova 1967, pág. 16 . 
2. Não se poderia escrever sôbre fundos de investimentos sem fazer alguma alusâo ao "Investiment Trust", porque o fato mercantil que nos ocupa teve inicio, em fins do século passado, na Escócia (Inglaterra). Estendeu-se aos EE.UU. onde teve e tem uma realidade florescente.

Todavia, a alusão será breve porque o objetivo dêste trabalho não é histórico nem pretende analizar as formas alienígenas. Èle visa apenas inserir êsse fato mercantil no nosso contexto jurídico.

No mundo anglo-americano os negócios de investimentos ajustam-se a duas formas jurídicas principalmente: à forma societária ou "corporation" e à forma contratual ou "trust".

A primeira forma, a da "corporation", não tem dificuldade de compreensão: coincide a grandes linhas com a nossa sociedade anônima, ressalvando tão sòmente a variabilidade do capital, a efeitos da sociedades de investimentos. Isto faz que a forma societária, contràriamente ao que possa parecer, é a forma jurídica preferida e cada vez mais em voga, no mundo americano.

A segunda forma, o "trust", é peculiar do âmbito jurídico anglo-americano. Como é sabido consiste essencialmente na bipartição da propriedade entre duas pessoas, entre o investidor, proprietário originário ou "settlor" e o administrador ou "trustee". Esta a peculiaridade anglo-americana, o administrador do investimento é também proprietário - embora com uma propriedade limitada segundo os lineamentos do contrato "trust agreement" ou "trust indenture" - assinado entre o instituidor e o administrador. ${ }^{2}$ Finalmente aparece um terceiro que é o beneficiário do investimento, chamado "cestui qui trust" e que no caso é, de ordinário, o mesmo investidor.

2. Ordinàriamente o contrato de "trust" é assinado não pelo investidor e o "trustee", mas por um interposto - a Companhia de investimentos, que capta os investidores - e o "trustee" ou banco que administra o acêrvo. Seguidamente o investidor obtém o certificado de 
Até aqui consideramos as formas jurídicas-societárias e contrato de "trust" - utilizados para trabalhar o negócio de investimentos. Não obstante isto, não se pode esquecer que na esfera anglo-americana as instituições não se organizam em função de formas juridicas, mas em função de formas práticas. Por isso convém lembrar a classificação que recolhe a Lei de Companhias de Investimentos de $1940^{3}$, que pode ser considerada como a carta magna dos investidores. Ela classifica os negócios de investimentos ${ }^{4}$ em três espécies diferentes:

a) os negócios de investimentos que emitem certificados de valor nominal fixo ou "Face-amount certificate companies".

b) Os negócios de investimentos constituídos com contrato de "trust" ou "Unit investiment trust" e

c) as "Management companies" ou companhias de administração, que são as mais desenvolvidas e as mais comuns - em contraposição com as duas espécies anteriores em franco declínio.

Ainda convém lembrar duas classes de "management companies", as abertas (open end) e as fechadas (closed end). Como a própria designação indica, as primeiras são aquelas em que o montante do fundo é ilimitado, podendo livremente participar novos investidores. Os "closed end" mantém constante o montante do fundo.

propriedade ou "beneficiary ownership". Isto porém não significa que a propriedade no "trust" se dividai entre o "trustee" e o terceiro beneficiário; acontece simplesmente que o proprietário originário é também beneficiário.

3. Investment Company Act of 1940.

4. Propositadamente chamâmo-los "negócios de investimentos", para não chamá-los companhias nem fundos, já que êstes vocábulos têm em nossa conceituação jurídica um significado distinto. Nos EE.UU. é indiferente que sejam sociedades ou fundos, aliás a problemática sôbre se os fundos são condomínios ou não, é irrelevante. 
Os fundos adotados no Brasil talvez equivalham "mutatis mutandis" às "management companies" do tipo "open end", também chamadas corretamente "mutual funds"

Os "mutual funds" tiveram nos EE.UU. nos últimos anos um ascenso surpreendente segundo cifras apresentadas pela NaIC "National Association of Investiment Companies". Em 1941 os ativos das associadas somavam US\$... $402.000,00$ enquanto que em 1964 ascendiam a US\$... $30.000 .000 .000,00$.

3. Os negócios de investimentos, realmente dedicados a essa atividade, são recentes no Brasil.

Não existe, por enquanto, uma história escrita dos investimentos no Brasil. Essa história, quando se escrever, poderá constar de duas partes: a história real e a história das fontes ou da legislação.

A história da legislação é fàcilmente reconstituível: a fonte principal foi o Decreto-lei $\mathrm{n}^{\circ} 7.583$, de 25.5 .45 conjuntamente com a Portaria $n^{\circ} 88$ de 08.6.45.

No ano seguinte 1946, surgiu o Decreto-lei $\mathrm{n}^{\circ} 9.603 \mathrm{e}$ posteriormente a Portaria 309 de 30.11 .59 que foi estatuto das companhias de investimentos e das de crédito e financiamento, até que em 14.04.70 a Resolução 145 do Banco Central do Brasil deu a regulamentação mais recente a atividade comercial dos investimentos. Legislação complementar esparsa houve, embora sem maior interêsse para o âmbito desta introdução histórica ao trabalho.

A história real dos investimentos no Brasil é mais difícil de ser escrita. Com anterioridade ao Decreto-Lei $\mathbf{n}^{\mathbf{0}}$ 7.583 , já havia companhias pioneiras dando início a esta atividade, pela simples razão de que os fatos mercantís ordinàriamente precedem à Lei -, embora, fôsse duma maneira rarefeita, suposto que se tratava de sociedades familiares, e por conseguinte fechadas ao público.

Em 1953, em revista especializada, pode-se lêr: "Embora as sociedades de investimentos procurem distribuir as 
ações de determinada indústria entre milhares de tomadores, elas próprias ainda canalizam os seus lucros a um reduzido número de beneficiados, capitalização contra-indicada no ramo". 5

Bernard Pajiste em 1958 ainda alertava: "deve-se evitar que as companhias de investimentos tomem o caráter: familiar ou fechado, que domina ainda o setor das sociedades anônimas no Brasil". ${ }^{6}$

O mesmo autor proporciona um dado objetivo sôbre as Companhias de Investimentos existentes. Diz que em 1953 havia no país 54 companhias de investimentos das quais apenas 23 tinham autorização da "Superintendência da Moeda e do Crédito" (Sumoc) que foi o organismo superior de crédito até a criação do Conselho Monetário Nacional. Essas 23 ou 54 companhias podem ser consideradas como as precursoras dos fundos de investimentos, que são os genúnos negócios de investimentos, sob o ponto de vista da abertura dos capitais das emprêsas ao grande público inversor.

Passo decisivo na história dos investimentos no Brasil foi dado pelo Fundo Crescinco, constituído aos 18 de janeiro de 1957, em São Paulo. Dito fundo trazia ao nosso mundo a "management company" do tipo "open end" de carteira diversificada, que é a modalidade hoje largamente adotada em sua versão brasileira dos "fundos em condomínio aberto".

A grande expansão dos fundos deu-se em 1969; no inicio dêsse ano eram poucos os fundos, ${ }^{7}$ enquanto que no fi-

5. Conjuntura Éconômica, n. ${ }^{\circ}$, Junho de 1953 pág. 48.

6. PAJISTE, Bernard, op. cit. pág. 58.

7. Os dados preliminares, ainda não oficiais, existentes no Banco Central do Brasil, são os seguintes:

$\begin{array}{lllll}\text { - Julho } & -1969 & - & 34 & \text { fundos } \\ \text { - Outubro } & -1969 & -56 & \text { fundos } \\ \text { - Dezembro } & -1969 & - & 69 & \text { fundos } \\ \text { - Janeiro } & -1970 & -111 & \text { fundos }\end{array}$ 
nal andavam à casa de uma centena. Dentre êles, 60 aproximadamente mostraram-se ativos no início de 1970 .

4. Dentre as instituições financeiras que operam o investimento, não se podem confundir os Fundos com as Sociedades. Estas últimas não apresentam maiores novidades e correspondem à figura da sociedade anônima. Em todo caso é necessário tocarmos, embora de passagem, estas sociedades, principalmente porque a Lei de Mercado de Capitais trouxe alguma novidade que dilata a concepção clássica da sociedade anônima: ela criou as sociedades de capital variável ou autorizado. ${ }^{8}$

A atividade de investimentos no Brasil, na atualidade, pode-se realizar através de três formas juridicas diferentes, a saber: "sociedades de investimentos de capital fixo"; "sociedades de investimentos de capital autorizado" e mediante "fundos de investimentos" As sociedades de investimentos terão sempre a forma anônima ${ }^{9}$ e quando dedicadas exclusivamente à aplicação em títulos e valores mobiliários, se distribuirem anualmente a totalidade dos rendimentos auferidos, não serão contribuintes do impôsto de renda. ${ }^{10}$

As primeiras, as "sociedades de investimentos de capital fixo", não trazem pràticamente novidade alguma, e hoje são quase inexistentes entre nós, embora històricamente fôssem a primeira forma seguida. Regem-se, no que tange à forma societária, pelo estatuto das anônimas: Decreto-Lei $\mathrm{n}^{0}$ 2.627, de 26.9.1940.

As "sociedades de investimentos de capital autorizado", embora ainda não tenham proliferado, reunem mais condições para isso do que as anteriores. O gravíssimo inconve-

No mês de Abril, mês em que saíu a nova Regulamentação (Res. 145) dos Fundos, aquêles que cotavam as suas quotas pelos órgãos de imprensa, ascendiam a 64 fundos.

8. Sociedades Anônimas de Capital Autorizado (Seç̧ão VII da Lei de Mercado de Capitais: Lei n. ${ }^{\circ} 4728$, de 14.7.65)

9. Art. $49, \S 2 .^{\circ}$ da Lei n. ${ }^{\circ} 4.728 / 65$

10. Art. 57, da Lei n. ${ }^{\circ} 4.728 / 65$. 
niente da fixidade do capital foi superado. ${ }^{11}$ As sociedades anônimas de capital autorizado poderão adquirir as próprias ações mediante a aplicação de lucros acumulados ou capital excedente, e sem redução de capital subscrito. ${ }^{12}$

Observa-se, todavia, que não dotou nosso legislador as sociedades de capital autorizado de tôda a agilidade que faz-se necessária para a prática dos investimentos. Encontram estas sociedades dois limites: um teto máximo, no capital autorizado, acima do qual não podem vender ações, a menos que celebrem nova Assembléia Extraordinária e seja autorizado capital superior; e um limite mínimo, no capital subscrito, abaixo do qual não podem descer. Outros empecilhos legais, ${ }^{13}$ ademais, tolhem a liberdade de ação destas sociedades, que pelo menos - para o ramo de investimentos - não parecem, por enquanto, as formas mais aconselháveis.

Não obstante isto a lei previu que "os fundos em condomínios de títulos ou valôres mobiliários poderão converter-se em sociedades anônimas de capital autorizado. ."14 Provàvelmente, com o correr do tempo, nova legislação abrandará as disposições sôbre as sociedades de capital autorizado, a fim de que também por essa forma seja possível praticar a atividade de investimento de modo satisfatório.

Nêste quadro da situação resulta que não sendo suficientemente numerosas, por enquanto, as sociedades anôni-

11. Se o capital variável, permitindo à sociedade resgatar as próprias ações livremente, se tivesse implantado mais cêdo entre nós, talvez não se tivessem aberto passo, tão fácilmente, os condomínios mobiliários. Um dos grandes obstáculos, sem dúvida, a dinâmica dos negócios de investimentos se encontrava precisamente na rigidez do capital das nossas sociedades anônimas, aliado à impossibilidade de recompra das próprias ações.

12. Art. 47, da Lei n. ${ }^{\circ} 4.728 / 65$.

13. Art. $45, \S 4 .^{\circ}, \S 5 .^{\circ}$; art. 46 , III, $\S 10^{\circ}, \S 2 .^{\circ}$, $3 .^{\circ}$ e $\S 4 .^{\circ}$.

14. Art. 50, da Lei n. ${ }^{\circ} 4.728 / 65$. 
mas de investimentos, restam os Fundos, como a realidade jurídico-econômica que merece ser estudada.

Em continuação abordaremos a natureza jurídica dos Fundos de Investimentos, não sem desconhecer as dificuldades que um estudo desta classe implica. A contribuição que, por ventura, se obterá tende a inclú-los entre os objetos "res universalis" - de direito de propriedade.

5. A copropriedade nada mais é do que uma maneira especial de apresentar-se a propriedade: é a propriedade em comum. Tem de especial, pois, que o proprietário, em vez de ser só uma pessoa, são várias pessoas, consorciadas na propriedade por fôrça da coisa comum, que as une.

À primeira vista pareceria que certo bem sòmente pudesse ter um proprietário. O têrmo propriedade, inclusive, deriva da palavra "proprium", que faz alusão a um só sujeito. Não obstante, a propriedade às vêzes, por fôrça de determinadas circunstâncias, pertence a vários sujeitos, que se chamam condôminos, consortes, comunheiros ou coproprietários.

Dissemos que o condomínio - que é tratado em quase todos os Códigos, entre os direitos reais - se produz em virtude de certas circunstâncias. Uma delas poderia ser, a título de exemplo, a sucessão de vários herdeiros nos mesmos bens. $O$ "de cujus" deixou os bens aos seus sucessores, os quais serão coherdeiros, enquanto não fôr dividida a massa.

É característico da propriedade em comum, de origem romana, ${ }^{15}$ que cada condômino possa usar por inteiro da coisa, e sôbre ela exercer tôdas as faculdades inerentes à propriedade uso, gôzo, desfrute - compatíveis com a indivisão. Pode inclusive, gravar a sua parte individida.

15. Há uma outra comunhão de inspiração germânica, em que os proprietários não podem dispôr da coisa. É a chamada "gesammten hand" ou copropriedade em mão comum. Nesta copropriedade germânica não existem qüotas, ou divisões ideais, das quais o coproprietário pudesse dispor. 
Fácilmente se compreende que esta situação se converte em ninho de conflitos ou, então, na indiferença mais absoluta por parte dos consortes para com a coisa. A razão da improdutividade de muitas áreas, freqüentemente, encontra-se no fato de serem copropriedades, cujos donos vivem de costas a elas, não querendo agir, receiando serem mal interpretados ou simplesmente, para não se dar a um trabalho, ao qual os demais, igualmente responsáveis, não se darão.

Finalmente, convém lembrar que as parcelas ideais ou qüotas em que se divide o condomínio não são partes determinadas do imóvel ou objeto, mas apenas frações ideais, indeterminadas. "A divisão entre condôminos é simplesmente declaratória e não atributiva de propriedade". ${ }^{16} 0$ condomino continua com acesso a todo o objeto, por inteiro, já que não se lhe atribuiu ou especificou parte real, que se corresponda com a parte ideal.

O estado em condomínio - como fàcilmente se depreende é um estado odioso. É conhecido o velho aforismo, deduzido pelo direito da vida prática, que diz: "Communio est mater discordiarum" O direito procura por todos os meios, através de seus dispositivos, tirar os coproprietários dessa situação. "Em diversos preceitos legais, timbra o legislador em ressaltar seu desaprêço pela comunhão: a) - quando estabelece a imprescritibilidade da ação divisória, uma vez que, segundo se expressa a lei, a todo o tempo, pode ser promovida a divisão; b) - quando dispõe que se a indivisão fôr condição estabelecida pelo doador ou atestador, entende-se que o foi sòmente por cinco anos (art. $630 ;$ c) - quando preceitua que o estado de indivisão não pode exceder quinqüênio, embora suscetível de prorrogação ulterior (art. $629 \S$ único). ${ }^{17}$

16. Art. 631, do C.C.B.

17. Barros Monteiro, Washington, Curso de Direito Civil, $3 .^{\circ}$ Vol. Direito das Coisas, Ed. Saraiva, São Paulo, 1967 pág. 211. 
Embora o direito tradicionalmente dispense um tratamento acre ao condomínio, êle é suscetível, porém, de adquirir uma dimensão prática e jurìdicamente mais tranqüila que, talvêz, os novos tempos venham descobrir. Referimo-nos ao conteúdo social que encerra e aos inumeráveis benefícios econômicos, quando bem disciplinado, que muito bem podem fazer dêle um instítuto interessante $e$ voluntàriamente procurado.

o homem, que é um ser inteligente, tem encontrado formas de vida comunitária, em que a propriedade é usada e desfrutada ordenadamente, por múltiplas pessoas. Não se trata de colocarmos a copropriedade comunitária como protótipo da relação sujeito-objeto, mas apenas de repararmos na sua possibilidade. Nada impede, nem "de jure" nem "de facto", que vários homens partilhem a propriedade de determinado bem.

Os conflitos habituais decorrem mais do caráter forçoso, não voluntário, do condomínio tradicional e, principalmente, da indivisão e de regulamentação insuficiente. Com isto não se pretende negar o egoísmo humano sempre presente, que ainda contribui mais a conturbar as relações entre condôminos.

O condomínio voluntário ,ao contrário, será pacífico, pela própria voluntariedade, muito mais na medida em que melhor se regulamentarem os interêsses e a divisão das partes.

De resto, "o direito de propriedade privada sôbre os bens, tem intrinsecamente inerente uma função social". ${ }^{18}$ Função esta que muito bem poderá ser acentuada, até o ponto de constituir-se, nalguns casos, um agrupamento humano em proprietário, compartilhando várias pessoas da propriedade.

6. Aquela visão clássica do condomínio, como situação desinteressante, não se poderia generalizar. Ela é

18. Mater et Magistra, 35. 
válida para o condomínio necessário - "condominium incidens" - que surge em decorrência de eventos, alheios à vontade dos coproprietários; não para outras situações condominiais propositadamente queridas ou buscadas.

Antes de passarmos à consideração das novas formas de condomínios, ou condomínios voluntários, dever-se-á analisar a possibilidade de vários indivíduos consorciarem-se voluntàriamente para serem coproprietários dum mesmo objeto, massa patrimonial, imóvel. Outrossim, dever-se-á prèviamente considerar se o fator "voluntariedade" não destrói a natureza do condomínio, passando então a ser sociedade.

obviamente, tôda sociedade tem um condomínio como substriato comum - todos os acionistas duma sociedade anônima por exemplo, são coproprietários dela; mas nem todo condomínio é sociedade. Em princípio o "status condominalis" não constitui nova pessoa jurídica por si, diferente da dos condôminos. A personalidade, núltima análise, decorre da graciosidade legal. Se a lei não outorgar a personalidade a certas comunhões voluntàriamente instituídas, elas serão simplesmente condomínios, sem personalidade legal.

A respeito da primeira questão suscitada - se várias pessoas podem se consorciar voluntàriamente - nada obsta a que duas ou mais pessoas se ponham de acôrdo para terem, em condomínio ou em comum, certa coisa. Inclusive o fato de poderem fazê-lo voluntàriamente é presságio de propriedade pacífica, uma vez que, além do mais, poderão através duma convenção ou acôrdo regulamentarem-se os direitos e as obrigações de cada um, a respeito da coisa. Em princípio, será um condomínio mais elaborado e tranqüilo que o condomínio comum, necessário ou civil.

Evidentemente, o"animus condominii" que dever-se-ia caracterizar pela integridade do senhorio ou intenção de que a totalidade da coisa nos pertence, ficará enfraquecido no caso. $\mathrm{O}$ coproprietário do condomínio voluntário sabe que 
entrou com uma parcela apenas e, porisso, tem consciência de ser proprietário duma parte, do quinhão ou parcela que se lhe atribui. Neste condomínio, o todo permanece unido em função do fim superior, normalmente de tipo econômico, que se persegue. Não obstante, a distribuição existe “ab initio"; mais ainda, será mantido o estado de parcelamento originário. Cada coproprietário continuará a ser dono da sua fração, embora integrada no condomínio pelos benefícios que dêste novo estado se auferirão. Aparece aqui o parcelamento ou divisão como conatural ao condomínio voluntário, mas sôbre isto voltaremos depois.

No que se refere à outra questão — se a voluntariedade destrói ou não o condomínio - a resposta é negativa. A vontade não só não destrói, senão que dignifica a copropriedade. Por outro lado, a vontade não é exclusiva das sociedades; não transforma ela por si só o condomínio em sociedade.

De resto, a personalidade jurídica, própria das sociedades, como já dissemos, é criação do direito, o qual a estende aos institutos e agrupamentos a que deseja dar personalidade, depois de satisfazerem determinados requisitos materiais e formais.

Nem todos os agrupamentos de homens gozam de personalidade, juridicamente falando, embora sejam sociedades sob o ponto de vista natural. O condomínio voluntário seria apenas uma sociedade natural ou agrupamento de pessoas, movidas por um fim comum; mas não será, de forma alguma, sociedade comercial legalmente existente, enquanto não fôr registrada ou aprovada pela autoridado competente; enquanto não for erigida enfim pelo dircito, como tal.

Admitida a possibilidade do condomínio voluntário, além do tradicional ou necessário, poder-se-íam considerar dois tipos principais de condominios voíuntários, em nosso direito atual: o "condomínio imobiliário" e o "condomínio mobiliário". Exemplo do primeiro se encontra regulamen- 
tado pela Lei do Condomínio e das Incorporações Imobiliárias $n .^{\circ} 4.591$, de 16.12.64 e pelo Decreto $\mathrm{n}^{\circ}$ 55.815 de 8.3.65; e os fundos, como exemplo do segundo, esparsamente, por Instruções e Portarias das autoridades monetárias, além da Lei de Mercado de Capitais (Lei n. ${ }^{\circ} 4.728$, de 14.7.65) e pela mais recente Resolução 145, de 14.4.70.19

Outra divisão clássica dos condominios é aquela que os considera "pro indiviso" e "pro diviso". Tradicionalmente, a divisão em quotas ou quinhões seria o passo prévio para superar o estado de indivisão e sair dêle. Todavia, no condomínio voluntário, o estado "pro diviso" é um estado passível de ser mantido, duradouro e próprio do condomínio voluntário. A divisão em partes permite, por um lado, ao participante ou condômino, vender sua parte em qualquer momento e abandonar, assim, o condomínio; sem, por outra parte, alterar a continuidade da massa condominal, formada pela unidade da coisa, e gozar assim, das vantagens próprias de um todo superior, unido.

Ainda poderíamos, em função da unidade orgânica da coisa, dividir os condomínios em: materialmente orgânicos e funcionalmente orgânicos. Com ef eito existem diferenças entre a unidade orgânica dum imóvel e a unidade orgânica de um fundo mobiliário. No primeiro caso a unidade da coisa é permanente, materialmente irredutível, de maneira que quando o proprietário de um andar o vende, outro novo proprietário o substitui, permanecendo a coisa sempre fìsicamente integra. No segundo caso, a saída do participante do fundo mobiliário significa a diminuição da massa patrimonial, mas sem que isto altere a sua unidade orgânica. A indivisibilidade material do imóvel é absoluta, enquanto que a do fundo é relativa, meramente funcional.

19. Outro exemplo de "condomínio imobiliário" podemos encontrar na copropriedade dos navios ou "parceria marítima". Exemplo de condomínio mobiliário haveria na copropriedade sôbre a quota indivisa, nas "sociedades por quotas de responsabilidade limitada" (Art. $6 .^{\circ}$ do Decreto 3.708 de 10.1 .19$)$.- 
Ao fundu convém uma grande massa de recursos, mas não o alteram substancialmente uma quantidade a mais ou a menos. Elle como um todo, orgânicamente, continua servindo às suas finalidades próprias.

7. As notas do condomínio necessário, que se regem pelo Livro II, Título II, Capítulo IV, do Código Civil Brasileiro são as seguintes:

1. Uma pluralidade de proprietários, chamados condôminos.

2. Uma coisa, massa ou objeto patrimonial, que se mantém unida "ex natura rei": por ser pràticamente indivisivel ou porque pela divisão, torna-se imprópria para atingir o fim a que se destina, e

3. A pertença de tôda a coisa, por intero, a cada um dos condôminos.

As duas primeiras notas são comuns a qualquer condomínio, porém, na última nota, o condomínio tradicional ou necessário, se diferencia do voluntário.

No condomínio voluntário (mobiliário ou imobiliário) a divisão é atributiva da propriedade, de maneira que cada participante tem direito à sua quota, à sua "pars divisa"; mas não é proprietário do todo - embora se possa teòricamente admitir um direito potencial ao todo.

O condomínio tradicional reduz-se, destarte, a um instítuto arcáico, acidental, impôsto pelas circunstâncias, ora aperfeiçado pelos mais modernos condomínios voluntários, estáveis, depurados de tôdas as imperfeições e arestas do condomínio tradicional, que considerou principalmente a copropriedade forçosa ou incidental.

8. Não resta dúvida quanto a caracterízação da moradia moderna, em prédios de apartamentos, como condomínio voluntário.

A propriedade verdadeiramente comum, contudo, reduz-se à mínima expressão. Na realidade só existe copro- 
priedade daquelas áreas e zonas - elevadores, escadas, terraços, porões... que é impossível dividir. Alguns autores consideram êste instítuto realmente como misto de propriedades individuais e copropriedades - a copropriedade só seria dêsses espaços comuns.

A existência da propriedade individual é inconteste. A Lei a reconhece quando fala em "Edificações ou conjuntos de edificações, de um ou mais pavimentos, construídos sob a forma de unidades isoladas entre si.. . . e constituirá, cada unidade, propriedade autonoma, sujeita às limitações desta lei."

$\S 10^{\circ}$ - Cada unidade será assinalada por designação especial numérica ou alfabética, para efeitos de identificações e discriminação.

§ 2. - A cada unidade caberá, como parte inseparável, uma fração ideal do terreno e coisas comuns, expressa sob forma decimal ou ordinária. ${ }^{20}$

Não existe dúvida, pois, quanto a divisão de todo o imóvel, numa série de unidades que pertencem aos diferentes proprietários. A propriedade exclusiva, individual de cada proprietário, está expressa no têxto legal que fala claramente em "unidades" e "propriedades autônomas". Todavia, não se poderia reduzir a existência do condomínio às áreas comuns "o terreno em que se levantam a edificação ou o conjunto de edificações e suas instalações, bem como as fundações, paredes externas, o teto, as áreas internas de ventilação, e tudo o mais que sirva a qualquer dependência de uso comum dos proprietários ... ... de unidades, ou ocupantes, constituirão condomínio de todos e serão insuscetíveis de divisão.. " ${ }^{21}$ já que o imóvel, como um todo, forma o condomínio, em virtude da sua unidade orgânica.

20. Art. $10^{\circ}$ da Lei n..$^{\circ} 4.591$ de 16.12.64. Os grifos são nossos.

21. Art. $3 .^{\circ}$ da Lei $n .^{\circ} 4.591$, de 16 de dezembro de 1964. 
O prédio tem uma unidade própria que alberga $e$ compreende cada apartamento. Estes encontram a sua razão de ser integrados no conjunto. Fora dêle, como unidades separadas, inexistiriam, seriam inconcebíveis. Eis aí, no todo, entitativo e distinto, o fundamento essencial do condomínio. Na melhor das hipóteses, podemos admitir proprietários autônomos no condomínio; mas sem chegarmos a destruir a unidade do objeto, do imóvel no caso.

Parece importante repisar a unidade da coisa, embora divisível e dividida a efeitos práticos, já que é característico dos participantes, no condomínio voluntário, integrarem-se no todo, precisamente, pelas vantagens que obterão no conjunto. O objeto, globalmente considerado, proporciona economia e benefício aos comunheiros, bem superiores àqueles que individualmente atingiriam.

Esta nota - a unidade de objeto - permanece no condomínio diviso e mobiliário que, em continuação, passaremos a considerar.

9. O condomínio mobiliário, diferentemente dos anteriores, não é mais o estado forçoso do direito das coisas; trata-se de instituto mercantil. Agora o objeto da copropriedade não será um bem corpóreo, mas serão valores, uma massa patrimonial de bens incorpóreos ${ }^{22}$ - que, juridicamente é considerada - objeto de propriedade.

Ja se viram acima, falando dos aspectos econômicos dos Fundos de Investimentos, as vantagens decorrentes da massa patrimonial ou carteira de valores formada com as aportações dos numerosos participantes. O Fundo alcança uma segurança, liquidez e rentabilidade diretamente proporcionais ao seu crescimento. Porisso ao objeto - massa patrimonial - convém a unidade; para atingir o seu desti-

22. O legislador pátrio já considerou como objeto da propriedade os bens incorpóreos, quando corporizou a propriedade literária, científica e artística, incluindo-as no Livro II do Direito das Coisas, do Cód. Civil. De resto, os valores possuem certa corporeidade e o Direito Comercial, repetidas vêzes, trata-os como "res corporales" ou "coisas". 
no. A carteira do fundo permanece unida, comportando-se como uma "res connexa".

Além disso, os outros requisitos do condomínio voluntário, quais sejam: vários proprietários e a divisão ideal do todo entre os participantes, dão-se também no condomínio mobiliário, que é condomínio "pro diviso".

A divisão, embora de caráter atributivo, òbviamente, não se contrapõe à unidade patrimonial do Fundo. Teremos, por um lado, a propriedade autônoma de cada participante à sua qüota, e por outro a copropriedade de todos a respeito do condomínio, globalmente considerado. Um participante não é proprietário do todo, ${ }^{23}$ mas apenas titular duma parte. Todos os participantes são proprietários do todo.

Reconhecendo a forma do "condominio" para os Fundos de Investimentos Mobiliários, não se ignora o alargamento que se está fazendo daquêle instituto. $O$ legislador, porém, desde 1959 vem se referindo incessantemente, a êsses Fundos com a designação de condomínios. Não se poderia cogitar que o legislador errasse, e menos ainda, que a lei habitualmente, estivesse eivada de impropriedades. Lógico, será pensar que está nascendo um novo instítuto, em parte coincidente com o tradicional condomínio ${ }^{24}$, e em parte com traços novos que o legislador e a doutrina, paulatinamente, trarão à tona. De resto, nalguns países europeus foi reconhecido o condomínio mobiliário, despido das durezas do condomínio forçoso ou

23. Pode-se admitir, acadêmicamente, a propriedade total, mas meramente potencial, e sujeita a tôda classe de limitações. A propriedade sôbre a quota, inclusive, já é propriedade limitada, sujeita a tôda uma série de restrições.

24. Diz-se, em parte coincidente com o condomínio tradicional, porque o instítuto civilista da copropriedade é suficientemente simples e vasto para abranger dentro do gênero, várias espécies e sub-espécies. o direito travou històricamente perseguição ao condomínio "pro indiviso", mas não ao condomínio "pro diviso". "Condominium indivisum est mater rixarum" - o itálico é nosso,- 
tradicional, como o instituto juridico adequado aos Fundos de Investimentos.

10. Tanto se a coisa, objeto do condomínio, fôr singular como se fôr universal ou coletiva - soma de objetos semelhantes - , cabe a possibilidade de fracionar a propriedade.

Com efeito, as coisas podem ser sigulares ou coletivas, abrindo estas últimas a possibilidade imediata da distribuição entre os vários condôminos, bastando dividí-las em suas unidades naturais. A mesma possibilidade, todavia, existe também em se tratando de "res singulares", em virtude do parcelamento em qüotas que, intelectualmente, sempre é possível realizar.

Imaginem-se coisas coletivas, um rebanho ou um conjunto de sacas de café. Se forem vários os proprietários da "res universalis", não resta dúvida que fàcilmente partilharão a coisa entre êles, acompanhando as unidades naturais: as ovelhas ou as sacas. O Fundo acionário tem características de ser coletivo, embora nem tôdas as unidades (ações, títulos) tenham igual valor. Freqüentemente, os individuos singulares que compõem os sêres coletivos têm diferenças entre si, mais ou menos acentuadas.

Ultrapassando, pois, a materialidade da coisa, objeto do condomínio, isto é, independentemente de que sua natureza seja singular ou universal, o que é irrelevante, é possível entender a comunhão como mera justaposição de propriedades parciais. Esta maneira de compreender a comunhão é especialmente válida se valorizarmos o papel que desempenha a abstração matemática na divisão da coisa.

Poder-se-ia chegar a basear a propriedade condominal para efeitos práticos, na relação entre o condômino e a sua parcela ideal.

Comentando esta concepção, diz Washington de Barros Monteiro que: "Circunscreve-se o direito do condômino a uma entidade abstrata, sua parte ideal na coisa comum. 
Existem assim no condomínio diversas propriedades intelectualmente parciais. A reunião dessas partes ideais forma o condomínio". 25

Admitida a grande função que a abstração matemática desempenha nos fundos em condomínio, é irrelevante falar em fracionamento atributivo ou meramente declarativo.

Pode-se muito bem admitir que o parcelamento abstrato não opera a divisão física, distribuição ou atribuição da coisa. Ela, a coisa - singular ou universal - permanece à margem daquela operação matemática, seguindo conexa o próprio destino. Mas, em se tratando de fundos de investimentos, a declaração da propriedade do participante sôbre a qüota equivale à atribuição. A atribuição reduz-se à declaração. $E$ isto porque a parte ideal é o critério objetivo, aquilo que motiva ou interessa o participante dos fundos e a expressão externa dos condomínios mobiliários.

A vida do condomínio discorre ordinàriamente, sem que os participantes travem contato com a materialidade do acêrvo. Entram e saem do fundo, adquirindo e resgatando qüotas, sem jamais se porem em contato direto com a coisa. Porisso, os títulos representativos das qüotas, os certificados de investimentos, mais uma vez se comportam como "res corporales" - a semelhança do que acontece com os títulos de crédito.

Destarte, a teoria da soma ou multiplicidade de propriedades parciais adquire importância. Os participantes são proprietários, de maneira imediata das qüotas ideais, e mediatamente são proprietários do acêrvo que corresponde àquelas qüotas.

Aparecem, assim, como que dois planos, o plano subjacente, da coisa real, formado pela carteira de ações,

25. Monteiro, Washington de Barros, Curso de Direito Civil, 3. ${ }^{\circ}$ vol. Direito das Coisas, pág. 203. 
e o plano intelectual formado pela soma das qüotas ideais. Este segundo plano adquire corpo e ganha destaque, facilitando a compreensão: do condomínio diviso, da propriedade dos condôminos, e do funcionamento dêste tipo especial de condomínio dos Fundos de Investimentos.

11. Os autores nacionais que, anteriormente, escreveram a respeito, embora não tenham acolhido o condomínio como o instítuto apropriado para os Fundos de Investimentos, quase todos êles, dalguma maneira, consideraram essa possibilidade. Era pràticamente impossível aceitar esta fórmula por duas razões: em primeiro lugar, porque o legislador, poucas vêzes ainda tinha mencionado esta nova figura, e em segundo lugar, porque era necessário alargar a interpretação do condomínio tradicional, para poder abranger o Fundo de Investimentos dentro do Condomínio.

Nos moldes do Código Civil, compreendido rotineiramente, não cabe o condomínio mobiliário; era necessário dar passo a um nôvo instituto mercantil, perante a insistência do legislador em definir como condomínios abertos os Fundos de Investimentos.

Cirne Lima considera os fundos na sua relação entre inversos e administrador, notando que é regulada essa relação pelo contrato de comissão. Não reconhece, entretanto, um todo nôvo, o condomínio formado pela massa patrimonial reunida por numerosos inversores. O condomínio poder-se-ia vislumbrar, segundo êste autor, em caso de haver liquidação, quando a carteira dos títulos adquiridos deva ser distribuída entre todos os inversores; porisso fala em "spes condominii", para significar o condomínio à hora final, quando o fundo deixará de existir. Em realidade, êste autor considera melhor o contrato ou mandato, indispensável para os fundos operarem.

AsHton diz que é inegável que existe uma copropriedade num fundo de investimentos, e há também semelhanças com o instituto jurídico do condominio, entretanto, deve 
ser pôsto em dúvida, se o rótulo de condominio é aplicável", ${ }^{26}$

Êste autor termina falando duma teoria nova: "a expectativa de condomínio, por ocasião da liquidação", ${ }^{27}$ que não é senão a teoria da "spes condominii" de Cirne LIMA a qual adere expressamente: "Pode pois concluir-se - diz - que, embora os fundos de investimentos brasileiros, do tipo aberto em regime de condomínio, devessem seguir a orientar-se pelas disposições do instituto do condomínio, regulado pelo Código Civil Brasileiro, tal não ocorre. Não são os fundos em condomínio aberto, aqui no Brasil, verdadeiros condominios, apenas representam êles,

26. Ashton, Peter Walter, Companhias de Investimentos, Ed. Financeiras, S.A., Rio de Janeiro, 1958, op. cit. pág. 56.

27. Esta teoria, chamada de "spes condominii" foi apresentada pelo Prof. RuY CiRne Lima. Ele acolheu o contrato de comissão como a fórmula para as Companhias de Investimentos estabelecerem seus planos de operaçôes legalmente no Brasil. "As companhias oferecem-se ao público em geral como possíveis comissários para inversores. 0 contrato de comissão entre a companhia e o inversor, quando concluído, assegura ao último, pretensão direta sôbre os títulos mobiliários em que seu dinheiro foi investido pela companhia (art. 170 do Código Comercial), mesmo se a companhia fôr a falência (art. 76 do Decreto-Lei n. ${ }^{\circ}$ 7.661, de 21.6.45).

Mas uma companhia de investimentos não poderia sobreviver com apenas um inversor comitente. A coexistência de muitos inversores, ou muitos comitentes, aparentemente constituirá entre os mesmos algo semelhante a um condomínio sôbre os valôres mobiliários em que seus fundos fôssem investidos. Condomínio é a palavra usada, mas em realidade êsse condomínio de inversores (comitentes) sôbre os títulos comprados em seu nome pela companhia (de investimentos) pode sòmente ser concekido após o término, relativamente, a todos os inversores, dos seus respectivos contratos de comissão com a companhia. Apenas quando todos os contratos de comissão houvessem terminado, seria possível pensar-se em condomínio incidente - "communio incidens" - que resultaria da entrega coletiva pela companhia de todos os títulos existentes, a todos os inversores existentes." RUY CIRNE LIMA, in "Trust and Agency" - estudo apresentado em Symposium sôbre Direito e Govêrno Brasileiros, na Faclildade de Direito de Míami University, transcrito por Ashton, Peter Walter, op. cit. à pág. 99 e 100. 
no máximo a "expectativa de um condomínio por ocasião da liquidação do fundo". 28

Un dos artigos do Código Civil que regulam o condomínio, - termina dizendo - sugere a possibilidade da aplicação duma teoria nova - que poderia aqui ser chamada de "expectativa de um condomínio por ocasião da liquidação" - a um fundo de investimento do tipo em condominio. ${ }^{29}$

O Prof. Barreto Filho, em determinada altura de seu conhecido trabalho, também aponta o condomínio mobiliário como solução, embora, pela rigidez do condomínio civil, não possa acolhê-la. Diz assim: "Encontramos, portanto, uma fórmula capaz de definir a verdadeira natureza jurídica do "investment trust" do tipo "open-end": uma comunhão ou condomínio, aberto, em que é dada a cada comparte a possibilidade de nêle ingressar ou dêle sair a qualquer momento." 30

Também Pontes de Miranda menciona o condominio, reparando nas designações usadas pelo legislador. "As referências — diz - a fundos em conta de participação e a fundos em condomínio mostra que se supoem fundos de investimento, em que os donos não concluiram sociedade entre si e apenas entraram em relação jurídica com a sociedade de investimento, como participantes de conta, ou,

28. Ashton, Peter Walter, op. cit., pág. 63.

29. Ashton, Peter Walter, op. cit., pág. 62. O artigo a que se refere é o art. 632, do Cód. Civil, que reza assim: "Quando a coisa fôr indivisível, ou se tornar, pela divisão, imprópria ao seu destino, e os consortes não quiserem adjudicá-la a um só, indenizando os outros, será vendida e repartido o prêço,..." Êste artigo, em verdade, apenas trata da liquidação dos condomínios quando a coisa fôr pràticamente indivisível, e a liquidação se realiza superando o estado condominal, vendendo a coisa e obtendo em lugar dela o equivalente em moeda (o grande meio de troca). Em seguida se distribuirá o prêço, proporcionalmente, entre os ex-coproprietários.

30. Oscar BarReto FilHo, Regime Jurídico das Sociedades de Investimento, pág. 154, Ed. Max Limonad, São Paulo, 1956. 
como proprietários de fundo, outorgaram poderes à sociedade de investimento, para as operações necessárias e úteis sem que se lhes altere a posição juridica de impropriedade

A referência, entende-se, não afasta a possivel fiduciaridade, em que os fíduciantes outorguem a transmissão fiduciária, ern comum ou cada um de per si, a despeito de ser uno o fundo fiduciário". ${ }^{31}$

Uma dificuldade maior à extensão do condomínio ao Fundo de Investimentos es/riba no caráter dinâmico dêstes fundos, enquanto o condomínio é de natureza estática êle, o condomínio, apenas exprime a relação entre os coproprietários e o objeto.

Tulio Ascarelli já levantou esta objeção: "A existência de um condomínio para uma atividade ulterior com terceiros, leva, imediatamente, à idéia de sociedade. Realmente, a disciplina do condomínio coaduna-se com a utilização direta, pelos próprios condôminos, dos bens objeto do condomínio, e não com o aproveitamento dêstes em operações para com terceiros; com uma situação estática (que pode, por isso, decorrer seja de um contrato, seja de fato diverso) e não com uma organização dinâmica (decorrente de um contrato que disciplina justamente o aproveitamento dos bens em operações para com terceiros) " ${ }_{32}$

Não há a menor dúvida, os Fundos de Investimentos, são organizações dinâmicas, como qualquer instituição mercantil, objetivando lucro. Porisso, a nova figura juridica do condomínio mobiliário, aproxima-se se quiser à sociedade, terá desta a dinâmica, o relacionamento com terceiros, na prática dos negócios. Esta será uma nota própria dos condomínios mobiliários, embora alheia aos condomínios comum e imobiiiário.

31. Pontes De Miranda, Tratado de Direito Privado, Tomo LI, Rio de Janeiro, 1966, pág. 308.

32. Tullio Ascarelli, Problemas das Sociedades Anônimas o Direito Comparado, pág. 204. 
12. Admitida a figura do condomínio mobiliário, para o Funclo de Investimenlos, falta estudá-los em seu funcionamento, faz-se mister explicar a sua dinâmica, a sua atividade, pôsto que os inversôres não trabalham - são coproprietários passivos, não ativos. Entra aqui, o mandato que os coproprietários outorgam ao administrador, mandato êsse expresso na forma de contrato de adesão, e que faz parte do próprio regulamento do Fundo, ao qual adere formalmente todo participante quando adquire a sua qüota. Ésse regulamento, no Brasil, consta ordinàriamente da chamada "carta proposta", que é uma simples carta assinada pelo participante, quando solicita o ingresso no Fundo, em que declara à sua concordância com as condições constantes dela. As condições à respeito, rezam aproximadamente assim:

a) Que o Fundo ora constituido poderá receber um número ilimitado de participantes.

b) Que se outorgam poderes a determinada instituição financeira, ${ }^{33}$ para que administre o Fundo e quaisquer direitos e ações relativos aos valôres que compõem a carteira do Fundo, e

c) que os novos investidores aceitam expressamente tôdas as cláusulas do Regulamento, devendo fazer a proposta em carta apropriada.

Em outros países, como na Itália ${ }^{34}$, o mandato consta no "certificado de propriedade", que é o documento repre-

33. Atualmente, podiem administrar Fundos as Sociedades de Crédito, Financiamento e Investimentos, os Bancos de Investimentos e as Sociedades Corretoras de Títulos e Valôres Mobiliários.-

34. Libonati, Berardino; diz - falando dos "certificados de Investment trust", italianos - que "No certificado devem se reproduzir as várias cláusulas do mandato, quais sejam, em primeiro lugar, os diferentes poderes do administrador e os critérios aos quais dever-se-á ater na atividade de investimentos" em "Holding and Investment Trust", A. Giuffré, Milano, 1969, pág. 631 . 
sentativo da participação no condomínio. Seja como fôr, o mandato é necessário para pôr a massa condomial sob a gestão do administrador, dando vida, assim, a uma classe de condominio que de outra forma, permaneceria inerte.

\section{Primeiras conclusões.}

1. Os Fundos de Investimentos requerem um instituto jurídico nôvo: o condomínio mobiliário.

2. O condomínio mobiliário coincide com o condomínio comum na pluralidade de sujeitos da propriedade, ou condôminos, e na unidade da coisa, objeto da propriedade. Ela permanece unida na consecução do seu fim patrimonial.

3. A espécie do condomínio mobiliário, como o imobiliário, é condomínio "pro diviso" em que cada coproprietário tem a propriedade de uma parte, representada pelo "certificado de investimentos".

4. O condomínio mobiliário é condomínio volutário, porque os coproprietários dêle participam livre e voluntàriamente visando seus particulares interêsses.

5. A necessidade do nôvo instituto decorre da nova forma de operar os investimentos, que atualmente se pratica no país, e que não se enquadra convenientemente nos instítutos existentes.

6. O condomínio tradicional apresenta alguns inconvenientes, principalmente o fato de ser instituto estático e próprio de bens corpóreos. Porisso faz-se necessário, querendo estender o condomlinio aos negócios de investimentos, supri-lhe êsses inconvenientes. O Condomínio mobiliário seria um instituto genuinamente comercial: quer dizer, dinâmico e característico de quaisquer mercadorias - especialmente de valôres mobiliários. 
7. O aproveitamento do condomínio, como instituto apropriado, está na trilha iniciada pelo legislador que, em repetidos documentos, designa com o nome de condomínio os Fundos de Investimentos. De resto, o condomínio, em si é um instituto tão simples e vasto que pode abranger as situações mais variadas.

A copropriedade de valores mobiliários é suscetivel de ulteriores regulamentações, que aperfeiçarão o instituto.

8. Finalmente, os coproprietários nomearão um administrador ou mandatário, servindo-se do contrato de mandato, o qual incumbir-se-á de administrar a massa condomial.

13. Não se poderia tratar juridicamente, da atividade comercial dos investimentos sem falar nas sociedades comerciais, isto por duas razões. A primeira, porque êsses negócios constituem-se de forma afim à societária: de fato, a generalidade dos autores pátrios que versaram sôbre a natureza jurídica dos Fundos de Investimentos, até o presente, se inclinaram pela "Sociedade em conta de participação", como a forma mais adequada. Em segundo lugar, não se pode esquecer, que os negócios de investimentos podem ser constituídos também como sociedades anônimas, ademais de como Fundo em condomínio. ${ }^{35}$

Existe a sociedade anônima como forma possível segundo a qual pode-se constituir e reger essa atividade, havendo, todavia, duas modalidades dentro dela. A lei fala expressamente em Sociedades de Investimentos, que poderão ser constituídas com capital fixo, nos moldes tradicionais, ou com capital variável ou autorizado, nos

35. Os fundos em condomínio de títulos ou valôres mobiliários poderão converter-se em sociedades anônimas de capital autorizado, a que se refere a Seção VIII, (art. 50, da Lei n. ${ }^{\circ} 4.728$, de 14.07.65). 
têrmos da Seção VIII, da Lei n. ${ }^{\circ} 4.728$ do Mercado de Capitais.

No item 4, acima já foi tratada a existência das Sociedades de Investimentos. Nesta parte tentaremos desclassificar a forma societária, para os Fundos em condomínio. Estes são condomínios mobiliários - não formam sociedade.

Se se chegasse a reconhecer a natureza de sociedade no condomínio mobiliário caberia perguntar, que classe de sociedade seria? Alguma das formas expressamente nomeadas no código comercial? Talves pudesse ser a "Sociedade em conta de participação"? Ou, pelo contrário, tratar-se-ía de sociedade inominada, sem existência legal? Abordamos êste aspecto, já que alguns autores acharam discutível a natureza dos Fundos de Investimentos, e como já dissemos - passaram a considerá-los como sociedades.

14. Sumàriamente, podem ser lembradas as caracteristicas de tôda sociedade antes de concluir se os fundos em condomínio são ou não são sociedades, e se têm ou não personalidade jurídica. Importa diferençar estas duas questôes porque nem todo condomínio é sociedade e nem

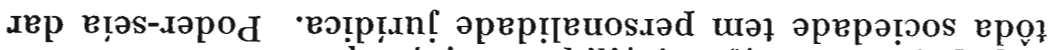
o caso que os condomínios mobiliários fôssem sociedades, porém, sem personalidade jurídica.

Os elementos essenciais de tôda sociedade, brevemente, são os seguintes:

$10^{\circ}$ - pluralidade de pessôas,

$2 .^{\circ}$ - patrimônio social,

$3 .^{\circ}$ - objetivo comum ou social, e

$4 .^{\circ}$ - "affectio societatis" ou espírito associativo.

"Celebram contrato de sociedade as pessôas que mùtuamente se obrigam a combinar seus esforços ou recursos, para lograr fins comuns". ${ }^{36}$

36. Art. 1.363, do Código Civil. 
Os tratadistas pátrios não enumeram entre os elementos constitutivos da sociedade um quinto requisito: o seu reconhecimento legal. Êste é necessário apenas para a existência legal da sociedade. ${ }^{37}$

Os três primeiros elementos — pluralidade de pessôas, massa de bens e determinada finalidade - são comuns "servatis servandis" às sociedades e aos condominios mobıliários.

Naquilo que respeita ao quarto elemento, "affectio societatis", o elemento diferenciador, no caso, caberia perguntar se o participante dum Fundo mobiliário tem ou não ânimo ou espírito de se associar com outros.

Convém reparar que a "affectio societatis" é diferente duma sociedade para outra, numa "sociedade de capital e indústria" é mais intensa concretamente que numa "sociedade anônima". Trata-se de requisito que, nalguns casos, quase reduz-se ao simples inscrever-se ou subscrever ações da sociedade sem demasiadas exigências. As disposições de alguns acionistas, numa sociedade anônima, não são muito diferentes das do participante dum condomínio aberto - são equivalentes.

Nos condomínios comuns, dado o seu caráter fortuito, involuntário e forcoso, falta clarissimamente, a "affectio societatis"; porisso muito bem diz o conhecido provérbio que "tôda sociedade é condomínio, mas nem todo condomínio é sociedade". No condomínio mobiliário, que é voluntário, será preciso excluir a "affectio" para que não se transforme em sociedade.

37 “Começa a existência legal das pessoas jurídicas de direito privado com a inscrição de seus contratos, atos constitutivos, estatutos ou compromissos no seu registro peculiar, regulado por lei especial, ou com a autorização ou aprovação do Govêrno, quando precisa" (art. 18 do Cód. Civil). No caso dos Fundos de Investimentos faz-se necessária a autorização e a inscrição no Registro dos seus documentos constitutivos. 
No condomínio mobiliário, por outro lado - e isto complica mais o tema - o participante mantém certo interêsse pela marcha do fundo:

$10^{\circ}$ - o participante sabe-se proprietário duma parcela pertencente a um todo superior;

$2 .^{\circ}$ - o participante acompanha o desenvolvimento do fundo; através de Balanços, composição da carteira, valôr diário das qüotas.

$3 .^{\circ}$ - o participante entra a formar parte e aporta voluntàriamente seus recursos ao Fundo, ciente dos seus fins lucrativos; e

$4 .^{\circ}-$ nos fundos, finalmente, há também atos comuns, as Assembléias Gerais, que se celebram como nas sociedades anônimas.

É necessário reparar que tôdas essas disposições que demonstra o participante pelo fundo, provam interêsse individual - dir-se-ía egoístico - em todo semelhante ao interêsse do proprietário pela coisa. A única variante surge porque não é o único proprietário - no condomínio outros tem interêsse igual e êsses interêsses devem ser conciliados.

A diferença entre a comunhão voluntária e a sociedade ${ }^{38}$, estriba nas disposições internas das pessôas, que são umas nos sócios e outras diferentes nos comunheiros. No comunheiro não se dá a relação interpessoal associativa,

38. Tradicionalmente tem-se diferenciado a comunhão da sociedade por duas notas: pela origem e pelo fim. A sociedade começa por um ato de vontade e tem fins econômicos. A comunhão, porém, independe da vontade e não pretende lucros, mas apenas a conservação da coisa que se tem em comum.

Esta maneira, poderíamos dizer história, de diferenciar êsses institutos, vale para distinguir a sociedade da comunhão incidental ou comum. Não vale, para a comunhão mobiliária que nos ocupa, e que como as sociedades tem origem consensual e finalidade econômica. Em realidade a diferença entre sociedade e comunhão era mais profunda do que aquela tradicionalmente considerada. 
característica do começo de tôda sociedade "- affectio" e que é preponderante no caso do associado. A sociedade, antes de nada, une os sócios entre sí para um fim comum, entretanto a comunhão relaciona apenas o sujeito com a coisa, é uma relação real, não entre pessôas. A relação dos coproprietários entre sí é irrelevante, porisso não se pode falar na "affectio" que implica sempre uma relação entre as pessôas dos sócios.

Caberia talvez a tentação de considerar o condomínio mobiliário como um instituto intermediário entre a sociedade e a comunhão. Não obstante, parece que a ausência de "affectio", isto é, ausência de relacionamento ou nexo entre os coproprietários com vistas a unir esforços para auferir lucro, é a nota característica de todo condomínio.

15. Dificilmente poder-se-ía negar, a primeira vista, a "affectio societatis" no condomínio voluntário, principalmente se fôr mobiliário; já que o interêsse econômico, além da adesão voluntária do participante, que soma os seus recursos aos dos demais, jogam um papel importante; todavia, a simples comunhão de interêsses, embora resultante dum ato jurídico voluntário, não constitui "affectio".

Ocorre ainda, em sociedades, que falta verdadeira "affectio societatis" nos acionistas. Não caberia exigir, porém, esta nota em todos e cada um dos acionistas de sociedades, reconhecidas como tais, pela própria lei.

A nota da "affectio societatis" tem sido muito discutida, até o extremo de a ter negado alguns civilistas, e comercialistas, como elemento substancial da sociedade. Em parte, isso é devido as divergências surgidas em tôrno da sua essência. Tratando-se de elemento subjetivo, preciso é reconhecer que êle difere de uma sociedade para outra. É diferente a "affectio" duma "sociedade de capital e indústria", e duma sociedade por ações.

Nas sociedades anônimas modernas, com milhares de acionistas, não existe mais sentido societário na grande 
maioria dêles. Entre os acionistas encontram-se os empreendedores, verdadeiramente interessados no contrôle e gestão da sociedade, que costuma ser um núcleo pequeno ligado por verdadeira "affectio" e depois, aquêles outros que são meros investidores ou especuladores, sem a menor "affectio societatis". As sociedades por ações, na atualidade, são sociedades porque aquêle núcleo de acionistas, realmente interessados, basta para satisfazer aquêle requisito. São como o fermento que enleveda a massa.

Todavia, em tôda sociedade há "affectio", isto é: há intenção de reunir-se segundo o instituto concreto chamado sociedade. É esclarecedora, neste sentido, outra maneira clássica de designar a "affectio", ela equivale ao "animus contrahendae societatis", - intenção de pactuar sociedade. Evidentemente a sociedade jurídica não é a única forma das pessoas se agruparem. Elas podem se reunir, sem quererem constituir sociedade.

Nos fundos de investimentos, não há núcleo algum de participantes empreendedores - na verdade o empreendedor é o próprio administrador, que tem a iniciativa do fundo e para isso congregou um primeiro grupo de inversôres. Os participantes ou qüotistas - repetimos - não têm sentido societário algum, são simples investidores que visam individualmente a valorização do seu quinhão, confiados na experiência e no "know how" do administradormandatário.

Não se reduz, destarte, a "affectio" à simples participação voluntária motivada pelo interêsse econômico; ela é principalmente combinação de esforços. O espírito associativo, implica uma disposição ativa no sócio. "Na sociedade, ao contrário do que sucede na comunhão, há a "affectio societatis", o que é quanto dizer, há cooperação ,todos os sócios trabalham e se esforçam para um fim comum, tendo em vista obter o mesmo resultado." 39

39. Gama, Afronso Dionysio, Das Sociedades Civis e Comerciais $2 .^{a}$ ed., Saraiva \& Cia., São Paulo 1929, pág. 10. 
Acresce notar que no condomínio não há resultado comum, próprio da sociedade como tal, já que o resultado é em todo momento, plus-valia ou minus-valia de cada quota. Conclui-se que o condomínio mobiliário, não se comporta como sociedade: soma de esforços ("affectio societatis") à procura de um resultado ou lucro comum. Mas bem se comporta como simples jôgo de interêsses justapostos, que passivamente beneficiam-se da valorização da coisa (da carteira de títulos).

Entramos, assim, numa fase do mercado de capitais, alargando-se, em que dêle vem participar pequenos capitalistas desconhecedores do que se passa no interior das instituições financeiras, e sem a menor intenção de envidar esforços para o seu progresso. Nasce assim, bem delineada, a figura não mais do sócio, mas do simples aplicador ou inversor, - ausente a "affectio".

O condomínio mobiliário, por conseguinte não pode ser considerado sociedade porłue nêle não se encontra, realmente, "affectio societatis".

16. Já vimos como a atividade de investimentos pode ser juridicamente realizada, de forma societária. Por outro lado, estamos agora considerando a possibilidade de realizar a mesma atividade de forma condomial, não societária.

Os elementos materiais tanto num caso, quanto no outro, são os mesmos. Um grupo de pessoas que reune uma massa de recursos, para aplicá-la, através de representantes especializados em títulos e valôres mobiliários, com a finalidade de auferirem lucro.

Observem-se, agora, as duas formas: a Sociedade Anônima de Investimentos e o Fundo em Condomínio. No primeiro caso o inversor é acionista e no segundo participante - no entanto, os elementos objetivos, num e noutro caso coincidem. A carteira do ativo, em ambos os casos, consta de ações, e o lucro aufere-se pela valorização da carteira. Poder-se-ía, seguindo adiante com esta análise, concluir dizendo que a mesma realidade material pode ser 
juridicamente contemplada tanto pela sociedade, quanto pelo condomínio.

Entretanto, as conseqüências da escolha duma ou de outra forma são diferentes. A sociedade imprime caráter ou personifica aquela realidade material, formada por pessoas e pelos bens que investem; enquanto que o condomínio tem índole diferente, continuando cada componente em sua própria individualidade.

O impácto do instituto sôbre aquela materialidade pessoas, bens e objetivos - traz, ademais consigo reflexos de outra ordem. A personificação societária, com o aparecimento duma nova pessoa, diferente da dos inversores, dá lugar ao nôvo sujeito de direitos e obrigações, e à "affectio societatis" dos inversores, que forçosamente serão animados por um espírito e mentalidade de sócios - diferente da isenção de ânimo própria do participante dum condomínio diviso.

Com estas considerações não se estão invertendo as coisas. A verdade é que da mesma realidade pode-se fazer uma sociedade ou um condomínio, e conforme as preferências se inclinarem por uma ou por outro, decorrerão disso tôda uma série de conseqüências.

No pais, por enquanto, os inversores estão se acostumando ao instituto do condomínio e, porisso, paulatinamente se espalha a mentalidade peculiar do condômino: independente e autônoma, que olha mais a própria qüota do que o patrimônio global. Se a forma societária se tivesse aberto caminho, a mentalidade predominante seria outra, a do sócio-acionista. Embora, no caso concreto do sócioinversor essas mentalidades não sejam demasiado divergentes - conforme já vimos.

Em resumo, há aspectos neste particular que decorrem mais do instituto escolhido, do que da materialidade objetiva. Aspectos que não precedem o instituto; senão que são seqüelas dêle. 
17 Não resta dúvida que muito devem os Fundos de Investimentos às técnicas contáveis e ao cálculo financeiro em geral. Sem êles não teria sido possivel conduzir, harmoniosamente, a multidão de condôminos, cada um dêles com o próprio interêsse que se reune no Fundo.

As ações que compõem o Fundo, òbviamente, têm valores diferentes. Umas são mais negociáveis, correspondem a sociedades tradicionais, lucrativas; outras tem menor liquidez, por serem de sociedades recém fundadas ou com pouca expectativa de lucros. Sôbre êste acêrvo heterogêneo, em princípio, seria difícil edificar um condomínio pacífico: todos os coproprietários, à hora da atribuição da propriedade, quereriam para si as ações melhores. A abstração matemática, no entanto, permite transcender a materialidade do acêrvo acionário e atribuir a cada condômino uma qüota ideal - desvinculada, completamente, do patrimônio concreto.

$\mathrm{Na}$ prática, pois, a relação de propriedade entre os condôminos e a coisa, se estabelece por mediação de algarismos. Há em primeiro lugar uma relação entre o sujeito e a parte ideal numérica. A relação entre a qüota ideal, representativa da coisa, e a própria coisa é subjacente.

São precisamente as propriedades matemáticas da divisibilidade e da abstração as que permitem, por um lado, o aparecimento do condomínio "pro diviso" e por outro a atribuição da propriedade a cada participante. A matemática é, destarte, mediadora entre os proprietários e a carteira heterogênea de valores, que formam o Fundo, harmonizando interêsses e criando uniformidade.

Alguns fundos preveêm o resgate das qüotas, em situações excepcionais, diretamente com títulos do acêrvo, em vez de serem resgatadas contra moeda. É evidente que o tratamento dispensado ao condômino que resgatasse por esta forma a sua qüota, é diferente do tratamento geral. As ações que ser-lhe-ão entregues serão melhores ou piores; em todo caso o histórico contábil, próprio delas, sempre 
será diferente do histórico das qüotas, que é a média das cotações de tôdas as ações que compõem o acêrvo. Por êste raciocínio prático, chega-se à conclusão de que, se o Fundo tivesse de ser liquidado, distribuindo tôdas as ações em carteira, entre todos os condôminos, alguns seriam prejudicados e outros beneficiados. Dificilmente se conseguiria contentar a todos. Uma vez mais, apareceria o espétro da antiga sentença - "Condominium mater rixarum" --, perante as dificuldades da divisão física, eqüitativa.

A solução legal, receitada para casos de liquidação é a venda da massa acionária, o que todavia se afigura difícil, já que se chega a hipótese de liquidar com o próprio acêrvo, quando não existe mais a possibilidade normal de vender os títulos.

$\mathrm{Na}$ verdade a grande utilidade da abstração matemática está a serviço do funcionamento diário e habitual dos fundos. É uma utilidade funcional. Entretanto, em circunstâncias extraordinárias, defrontar-nos-emos com a dura realidade dum acêrvo heterogêneo, impossivel de ser dividido igualitàriamente. Estas situações de exceção, de resto, já se apresentaram nalgumas ocasiões na história dos "Investment Trust". Representam para os administradores de Fundos aquilo que as "corridas" — da gíria bancária representam para os estabelecimentos de crédito. É o emperramento do negócio perante a impossibilidade momentânea de criar disponibilidade.

Concluindo. Sem o auxílio da abstração matemática não teria sido possível fazer do condomínio tradicional o instituto útil com que se conta modernamente. A matemática é o invólucro que envolve o acêrvo do condomínio mobiliário, protege-o e proporciona-lhe condições de vida vigorosa.

O valor e o significado concreto da matemática nos fundos em condomínio, prova, por outro lado, a ausência de "affectio". Em verdade, a relação intencional de interêsse objetivo e subjetivo, que se estabelece, medeia apenas 
entre o participante e a sua qüota ideal. O participante não tem acesso direto ao acêrvo - que só conhece indiretamente. O participante, ao igual, horizontalmente, nada sabe dos demais condôminos, que supõe eqüitativamente tratados. A perfeição ideal da qüota é tal que evita qualquer outra vinculação, intencional, do participante. Êle só se relacionou com uma qüota pura. Porisso, não se encontra "affectio societatis" nos fundos.

18. Interessa, ora, recordar as peculiaridades da sociedade em conta de participação, porque na ausência de outra fórmula mais satisfatória para os Fundos de Investimentos, os autores nacionais têm-se inclinado por esta.

Tem esta sociedade a característica de não gozar de personalidade, como convém aos Fundos. A personalidade existente é a do sócio ostensivo comerciante. Êle arrisca e se responsabiliza por tôdas as importâncias, que os sócios ocultos confiaram-lhe, como se fôssem dêle perante terceiros, - salvo se se provar, naturalmente, que os terceiros sabiam da existência de contas de participação.

Realmente, trata-se de participação isolada, em determinada operação de algum comerciante, que se realiza apostando certa importância para levá-la a cabo. É uma associação momentânea, acidental; porisso, a conta de participação, também é conhecida como sociedade momentânea ou sociedade acidental. Poderíamos chamá-la de sociedade menor, já que, realmente, é uma sociedade esporádica, raquitica.

O Código Comercial diz que "quando duas ou mais pessoas, sendo ao menos uma comerciante, se reunem, sem firma social, para lucro comum, em uma ou mais operações de comércio determinadas, trabalhando um, alguns ou todos em seu nome individual para o fim social, a associação toma o nome de sociedade em conta de participação, acidental, momentânea ou anônima". ${ }^{40}$

40. Art. 325, do Código Comercial. 
Esta sociedade não está sujeita às formalidades prescritas para as outras sociedades. Não se registrando, por conseguinte, nem alcançando personalidade juridica. Tratase, porém, de sociedade, já que tem um fim social que interessa a ambas as partes: o lucro comum. A "affectio societatis", como nas grandes sociedades comerciais mais modernas, reduz-se, também ao investimento econômico numa operação que o direito chama de "sociedade".

Todos os autores que aderiram a esta forma societária, reparam simultâneamente, na sua inadequação ao dinamismo a agilidade dos Fundos de Investimentos. O Prof. Barreto Filho nota: "O contínuo afluxo e refluxo de capitais fornecidos ao Fundo ou dêles retirados, por centenas ou milhares de participantes, evidencia que êsse novo tipo de emprêsa financeira, não pode enquadrar-se, às mil maravilhas, nos moldes da vetusta conta de participação". ${ }^{41}$

A conta de participação, para acabar, è um instituto jurídico insuficiente e sem a categoria que se faz necessária para compreender o volume de negócios dos Fundos de Investimentos, já em marcha no país e no mundo.

De resto, esta sociedade deve-se a um êrro, na acolhida que o código francês dispensou aos empréstimos que particulares fazem a comerciantes. $O$ que deveria ser uma simples relação creditícia, baseada no contrato de mútuo, foi extravasado para contrato de sociedade. Êsse engano foi repetido pelos códigos que se inspiraram no francês, como o nosso. Não se poderia, agora, de uma relação efêmera entre um comerciante e um conta-correntista, fazer o instítuto conveniente aos Fundos de Investimentos que surgem com os sinais dos empreendimentos duradouros, e que necessitam, portanto, duma estrutura jurídica harmoniosa, estável, coerente e acabada.

Chega-se, por êste caminho, à conclusão de que aos Fundos de Investimentos não convém encaixá-los numa

41. Oscar Barreto Filho, ob. cit., pág. 194. 
forma societária absolutamente insuficiente. Faz-se mister criar um instituto novo em que se possa acolhê-los adequadamente. É tarefa ingrata a de pretendermos encaixar novas realidades da vida jurídico-mercantil, nos institutos pré-existentes. Natural seria introduzir modalidades ou variantes nos institutos consagrados e até criar outros modelos, para dar a devida forma científica aos novos negócios.

Se não se abrirem passo numa nova figura, cairão não sem certa propriedade, na "sociedade em conta de participação", como de resto já aconteceu com os Fundos de Participação, chamados de "acceptance" ou mercantís, ${ }^{42}$ à falta de outra solução melhor. Destarte, alguns doutrinadores nacionais já começaram a conceituá-los dentro dessa estrutura jurídica.

Outra alternativa seria reconhecê-los como simples sociedades de fato ou irregulares, sem personalidade juridica. Esta probabilidade sempre existirá, perante o aspecto societário que alguns quererão entrever no condominio mas ela é compatível com a nova figura que se propõe do "condomínio mobiliário".

Com o passar do tempo, a resistência inicial, que encontrará o condomínio mobiliário, irá diminuindo e o aspecto societário, que poryentura existir, cairá simultâneamente em declínio. Na verdade os institutos mercantís, na atualidade, implicam mudanças profundas no próprio cerne das sociedades. $O$ próprio poder foi cindido. Os chamados sócios-acionistas das grandes sociedades não tem poder de decisão. A decisão, o mando, corresponde aos administradores, que são os únicos técnicamente preparados para tomar decisões. Os inversores, participantes e acionistas proporcionam-lhe apenas os bens, a massa sôbre a qual o administrador terá poder decisório.

42. Os Fundos de "acceptance" extinguiram-se, em $31 / 12 / 69$, por decretação do Banco Central do Brasil. 
Na Alemanha, já foi acolhido o condomínio com a "Gesetz über Kapitalanlazegesellschaften", ${ }^{43}$ em que se afirma que entre os inversores medeia uma relação de copropriedade, não uma relação societária. Da mesma forma, acolheram o "Investment Trust", como condomínio, a Suissa, a Espanha, e mais recentemente a Italia, - paises de profunda tradição romanística.

O legislador pátrio é louvável, havendo-se adiantado à doutrina, na solução esboçada, quando insistentemente designa os Fundos de Investimentos sob o rótulo de condomínios.

19. Entre as pessoas jurídicas o direito conhece, ademais das "universitas personarum" ou sociedades, as "universitas rerum" ou fundações.

Uma fundação é constituída por uma massa patrimonial - conjunto de coisas, "universitas rerum" - destinada a determ nado fim. Eis aí dois pontos de coincidência com o condomínio mobiliário. O objeto é a massa patrimonial, tanto em se tratando de um condomínio, como em se tratando duma fundação. Por outro lado, em ambos os casos, se persegue uma finalidade, confiando dita massa ao administrador, que tem a incumbência de aplicá-la.

Em virtude dessas coincidências já se originaram confusões por parte daqueles que quiseram verter o instítuto saxônico do "trust", nas "fundações romanas". Tampouco pode ser esquecido que, nalguns casos, os negócios de investimentos - que nos interessam - são realizados mediante a contratação de "trust" - "trust indenture" — na área anglo-americana.

A diferença fundamental, entre o condomínio e a fundação, radica na titularidade da propriedade. No caso do condomínio, os titulares da propriedade são os condôminos, enquanto que nas fundações surge uma nova pessoa - a

43. Lei de 16.4.57, que criou as Kapitalanlagessellschaften ou sociedades especializadas na administração de Fundos. 
personalidade jurídica própria da fundação - diferente da do instituidor, a qual passa a ser proprietária do bem.

Essa a concepção antiga que deve ser considerada. Poderá, ainda, haver casos, no condomínio mobiliário, em que o beneficiário não seja o investidor, mas um terceiro. Ou poderá haver casos de fundações em que beneficiário seja o próprio instituidor. Isto não obstante, a diferença fundamental persistirá. A "fundação" tem personalidade própria, diferente da do instituidor-fundador e da do beneficiário, e a ela pertence a propriedade da massa patrimonial. O condomínio, por outro lado, não tem personalidade própria, pertencendo os bens aos respectivos coproprietários - sejam êstes aplicadores ou terceiros - beneficiários. ${ }^{44}$

De resto, outra diferença relevante estriba no caráter público que adquirem as fundações. Nosso direito começou denominando-as: "estabelecimentos de utilidade pública". "Velará pelas fundações o Ministério Público do Estado". 45 "Aquêles a quem o instituidor cometer a aplicação do patrimônio. ., formularão logo os estatutos da fundação projetada, submetendo-os em seguida à aprovação da autoridade competente". ${ }^{46}$ "Para se poderem alterar os estatutos da fundação, é mister: .. que seja aprovada pela autoridade competente" ${ }^{47}$ a reforma.

O condomínio não adquire êsse interêsse público, pelo simples fato de tratar-se de propriedade privada. Isto, no

44. Considera-se a hipótese em que o inversor nomeia titular da qüota outra pessoa, um parente ou amigo. Neste caso, o beneficiário será proprietário e o administrador emitirá o "certificado de propriedade" em nome dêle. Pode, ainda, o proprietário nomear um usufrutuário, permanecendo êle com a quota originária, e transferindo em favor do usufrutuário as "plus valias" e valorizações, em geral, da qüota. Tôdas estas combinações, e outras, são perfeitamente cabíveis. Entretanto, a propriedade será sempre de alguém, nunca do condomínio, que não é titular de direitos por não ser "persona".

45. Art. 26 do Código Civil.

46. Art. 27 do Código Civil.

47. Art. 28 do Código Civil. 
entanto, não evita que, pelo seu dimensionamento social como tôda atividade creditícia e bancária - com o correr do tempo vão constituindo alvo de zêlo estatal.

Finalmente, também nos aspéctos extrínsecos se diferencia o condomínio mobiliário da fundação. O contêxto em que se inserem as fundações é diferente do contêxto dos Fundos em condomínio aberto. Ordinàriamente, a primeira é um instituto a serviço de pessoa ornada pela riqueza, que decide destinar determinados bens a um fim altruísta. 0 beneficiário -- instituição de caridade, artística, cultural. ., - é assim sujeito passivo do gesto magnânimo do fundador. O condomínio não tem essa elevação, está a serviço do aplicador comum que visa o próprio interêsse. $O$ condominio se insere plenamente no corriqueiro mundo dos negócios.

\section{Conclusões finais.}

1. O condomínio mobiliário coincide "Servatis Servandis" com a sociedade em estar formado por várias, ter fim próprio e possuir patrimônio.

2. O condomínio mobiliário, embora de caráter voluntário e de fins lucrativos difere da sociedade, pela ausência de disposições associativas ou "affectio societatis" entre os condôminos.

3. O condomínio mobiliário não alcança a personalidade jurídica. Portanto, os bens não pertencem a outra pessoa, diferente da dos condôminos. Os bens continuam pertencendo aos inversores.

4. No condomínio mobiliário se encontra multiplicidade de propriedades parciais convergendo sôbre a "res universalis" ou massa do fundo.

5. Os coproprietários interessam-se pela sua qüotapropriedade e pela valorização dela; mas não mantêm nenhuma relação, lateralmente, com os demais condôminos. Entre êles não há "affectio societatis" 
6. A copropriedade no condomínio mobiliário é concebida como um feixo de propriedades justapostas, independentes entre si, acerca da massa condomial. Cada condômino é proprietário duma parte da massa. Todos os condôminos são coproprietários de tôda a massa.

7. A massas do fundo, embora permaneça unida para a consecução de seu destino, e goze duma unidade orgânica funcional, é divisível matemática e intelectualmente em qüotas. Esta fórmula, permite precisamente a criação e continuidade harmônica dos fundos, com muitos coproprietários duma mesma carteira de valôres.

8. A sociedade em conta de participação parece um instituto jurídico frágil, para abraçar os fundos de investimentos. 0 sócio-participante visa uma participação no lucro do sócio ostensivo e não valorização de coisa própria.

9. A iniciativa do negócio de investimentos pertence ao administrador. Êle lança o Fundo. Êle é o comerciante - Banco de Investimentos, Companhia de Investimentos ou Sociedade Corretora primeiro interessado em auferir lucro, que se arrogará a posição de administrador e mandatário. O nucleo inicial dos empreendedores ocupam a posição de administradores, não a de sócios.

10. Em seguida surgirão numerosos investidores, sem caráter empreendedor, que após entregarem recursos ao administrador e outorgar-lhe mandato, permanecerão meramente passivos aguardando a valorização das suas participações. Os investidores não atuam, nem envidam esforços.

11. O contrato de comissão mercantil que, na prática, e agora por imposição legal, se utiliza, exclui a possibilidade dos fundos terem personalidade pró- 
pria. O administrador-mandatário tem a sua própria personalidade e administra uma massa de bens mobiliários. Os participantes adquiriram qüotas e continuarão sendo proprietários delas, sem perderem a própria personalidade. A comissão mercantil pressupõe duas pessoas - nisso difere do mandado intra-societário de eleição de diretores.

12. O legislador sempre, em todos os documentos legislativos, chamou de condomínio os fundos de investimentos.

\section{Bibliografia consultada.}

ASCARell, Tullio, Problemas das Sociedades Anônimas e Direito Comparado, 2. ${ }^{\text {a }}$ Ed., Ed. Saraiva, S. Paulo, 1969.

Ashton, Peter Walter, Companhias de Investimentos, $10^{\mathrm{a}}$ ed., Ed. Financeiras S.A., Rio de Janeiro, 1963.

BARreto Filho, Oscar, Regime Jurídico das Sociedades de Investimento, pág. 154, Ed. Max Limonad, São Paulo, 1956.

Barros Monteiro, Washington, Curso de Direito Civil, $3 .^{\circ}$ Vol., Direito das Coisas, E'd. Saraiva, S. Paulo, 1967.

CAssiba, Vincenzo, I Fondi Comuni di Investimento $e$ loro possibilitì di inserimento nel sistema bancario italiano, G. Giappichelli ed., Torino, 1970.

CoRet, Alain, Le Condominium, Lib. Générale de Droit et de Jurisprudence, Paris, 1960.

DE RAvel, Roland R., Les Sociétés d'Investissement: Etude Juridique, Economique et Financière, Sirey, Paris, 1959.

DOANE, C.R. \& Hills, E.J., Investment Trusts and Funds. From the Investor's Point of View, Great Barrington, Massachusets, 1959.

Fossatr, Giorgio, Borsa, Azionariato Popolare, Fondi Comuni di Investimento, A. Giuffrè, E., Milano, 1969.

Gama, Affonso Dionysio, Das Sociedades Civis e Comerciais, 2. ${ }^{\mathrm{a}}$ ed., Saraiva \& Cia., S. Paulo, 1929.

LiBonatr, Berardino, Holding e Investment Trust, A. Giuffrè, Milano, 1969. 
Martin Ovindo, José M., Regimen Juridico y Fiscal de las Sociedudes y Fondos de Inversion Mobiliaria, Ed. Banif, Madrid, 1967.

Nigro, Mario, Profili Pubblicisti del Crédito, A. Giuffrè Ed., Milano, 1969.

PAJISTE, Bernard, Investimentos, 2. ${ }^{\mathrm{a}}$ ed., Ed. Financeiras S.A., Rio de Janeiro, 1958.

Perreira, Caio Mario das, Condominio e Incorporações, $2 .^{\mathrm{a}}$ ed., Ed. Forense, Rio de Janeiro, 1969.

PERLETTI, G., Funzione Economica dell'Investment Trust, em L'Investment Trust nelle esperienze $e$ nei progetti europei, Cedam, Padova, 1967.

Pontes DE MiRanda, Tratado de Direito Privado, Parte Especial, Tomo LI, 2. ${ }^{a}$ ed., Ed. Borsoi, Rio de Janeiro, 1966.

PugliatTI, Salvatore, La Propvietá nel Nuovo Diritto, A. Giuffrè, Milano, 1964.

SEann, Jean-Patrice, Les Sociétés d'investissement en droit Français et Comparé, Nancy, 1956.

WeIsman, Rudolph Leo, The Investment Company and the Investor, $1 .^{a}$ ed., Hayer, New York, 1951.

Zunino, Antonello, Riforma delle Società per Azioni, società di investimento mobiliare $e$ fondi comuni di Investimento, em "Mondo Economico", I.S.E., Milano, 19.XI.66. 